\title{
A Comparative Analysis of Nonprofit Policy Network Governance in Canada
}

\author{
Peter R. Elson \\ Mount Royal University \& University of Victoria
}

\begin{abstract}
Across Canada, provincial governments and nonprofit network leaders are engaged in a "third wave" of consultations, policy dialogues, and policy alignment strategies. Unexplored to date is how nonprofit policy networks are governed and structured. Network structures could have important implications for policy management and any bilateral collaboration agreements with provincial governments. This is a new point of analysis for both public administrators and nonprofit network leaders. The alignment of network governance in four structural dimensions is analyzed, as are parallel nonprofit policy network structures within provincial governments and select nonprofit policy outcomes.
\end{abstract}

\section{RÉSUMÉ}

Au Canada, les gouvernements provinciaux et les dirigeants de réseaux à but non lucratif se sont engagés dans une "troisième vague » de consultations, dialogues politiques et stratégies d'alignement politique. Inexplorée jusqu'à ce jour est la manière dont les réseaux d'action publique à but non lucratif sont gouvernés et structurés. Pourtant, la structure des réseaux pourrait avoir des implications importantes pour la gestion politique et tout accord de collaboration bilatérale avec les gouvernements provinciaux. II s'agit ici d'un nouveau sujet d'analyse, tant pour les administrateurs publics que pour les dirigeants de réseaux sociaux. Cet article évalue la division en quatre dimensions structurales de la gouvernance des réseaux, les structures parallèles des réseaux d'action publique à but non lucratif au sein des gouvernements provinciaux et certains résultats émanant de politiques à but non lucratif.

Keywords / Mots clés Network governance; Nonprofit sector; Government relations / Gouvernance de réseaux; Secteur à but non lucratif; Relations 


\section{Elson (2015)}

\section{INTRODUCTION}

Across Canada, provincial governments and nonprofit network leaders are engaged in a "third wave" of consultations, policy dialogues, and policy alignment strategies. The first wave took place in the early 1970s, the second during the mid-1990s to 2005, and the third wave is underway (Elson, 2014). When the first National Survey of Nonprofit and Voluntary Organizations (Hall, de Wit, et al., 2005) was first released in 2004, there was a new appreciation by both provincial governments and their respective nonprofit sector constituencies that this was a substantial relationship that could be measured not only in policy proposals, services rendered, and volunteer efforts, but also in terms of employment and economic growth.

In recent years, provincial governments and nonprofit policy networks have signed collaboration documents outlining principles of nonprofit sector-government engagement that commit the government-at least on paper-to fostering a productive, interdependent relationship with the nonprofit sector (Carter \& Speevak Sladowski, 2008; Elson, 2011b).

This development alone could be considered remarkable, given the complex mix of nonprofit organizations with a significant variation in size, mandate, and focus (Hall, Barr, Easwaramoorthy, Sokolowski, \& Salamon, 2005). Provincial governments relate to the nonprofit sector in a variety of ways that are formal or informal, centralized or clustered (Elson, 2014). At the same time, government policies are often in a state of flux, subject to both election cycles and changing policy priorities. This article focuses on the "Third Wave" provincial nonprofit policy networks and institutional forms that have been developing since 2006 (Elson, 2012). So how do provincial nonprofit policy networks, with a focus on a collective voice for the nonprofit sector, manage nonprofit sector policies and their related network governance practices? And once this is known, can any inference about the nature of nonprofitgovernment relations be made?

\section{RESEARCH FRAMEWORK}

Network governance, as defined by Jurgen Willems and Marc Jegers (2012), is used here as a framework to examine the degree of centrality and formality associated with the provincial nonprofit policy networks. This research uses the operational definition of policy networks cited by Annica Sandström and Lars Carlsson (2008); namely that policy networks are "organized entities that consist of actors and their relations engaged in the process of collective action for joint problem solving" (p. 498).

The relationship between provincial governments and their nonprofit sectors has been systematically monitored by this author to identify network governance changes, including internal network governance structures. The monitoring of structural changes was triangulated by key informant interviews, public reports, and websites within provincial governments and the nonprofit sector. Over a six-year period (2009-2015), recurring and singular confidential interviews were conducted with senior policy makers and nonprofit policy leads in provincial governments and representatives of provincial intermediary nonprofit organizations. In total, 65 semi-structured interviews were conducted in intervals of approximately 18 months across all ten provinces. Of the 65 interviews, 31 interviews were conducted with government officials and 34 with nonprofit sector representatives. Where the comments from a particular interview have been cited, they have been coded by province; otherwise the interview citations reflect a summary of commentaries across multiple jurisdictions. Network governance structures do not simply appear, but are determined by decision-makers, government policy officials, and nonprofit network leaders alike, based on what form is believed to be most likely to be effective at the time (Provan \& Kenis, 2008). Thus, 


\section{Elson (2015)}

network governance, even within established structures, is in a continuous state of flux or adaptation to both internal and external pressures.

The policy network itself is the designated unit of analysis, and within this analysis both network and governance perspectives are combined. Networks are defined as a set of actors, or nodes (e.g., apex provincial nonprofit organization or network), with relationships among these nodes (Provan \& Kenis, 2008). Several network types have been delineated, including Carey Doberstein's (2013) metagovernance analysis, but those most compatible with this analysis are goal-directed networks, which "have become extremely important as formal mechanisms for achieving multi-organizational outcomes, especially in the public and nonprofit sectors where collective action is often required for problem solving" (Provan \& Kenis, 2008, p. 231). This focus brings to the fore the articulation of goals, either for nonprofit policies or the nonprofit sector at large.

A structural-functional definition of the nonprofit sector policy arena was used for this study, namely sectoral policy networks that are specifically designed to give a collective voice to and engage in systematic nonprofit policy dialogue. Bilateral policy or program discussions between individual ministries and their nonprofit sector constituencies in areas such as social services, arts, agriculture, or recreation, while valuable, are largely excluded in this analysis; but all instances of collective policy action are included. This macro-level analysis, while missing the nuances of specific bilateral initiatives, is intended to provide a broader perspective and reflect the collective policy of either government on the one side, or the nonprofit sector on the other. There are two notable exceptions. In Saskatchewan and New Brunswick there is a government-directed network that provides a venue for policy implementation that includes nonprofit sector representation (the Regional Intersectoral Committees in Saskatchewan and the Community Inclusion Networks in New Brunswick). What follows here is an examination of recent trends within and across Canadian provinces.

A cautionary note must be sounded: Several provincial governments have undergone substantial shifts in the importance placed on nonprofit sector relations, aligning such relations to culture, human services, or labour market policy priorities. Others have developed a broader nonprofit sector relations policy strategy and established a hub at a senior level of government. Nine of Canada's ten provinces have been engaged in some form of deliberate, sustained engagement in nonprofit sector-government relations policy (Campbell \& Speevak Sladowski, 2009; Carter \& Speevak Sladowski, 2008; Elson, 2010).

\section{NETWORK GOVERNANCE}

Willems and Jegers (2012), it is important to examine the reinforced expectations of behaviour or performance in provincial-nonprofit sector relations. Trust is critical for network performance and sustainability, particularly its distribution and reciprocation among network members (Provan \& Kenis, 2008). Goals and goal consensus is a second dimension of network governance. Lead network organizations assume most strategic and operational decisions, particularly when other network members are only partially committed to a network-level goal, (e.g., variance in the relation of any particular nonprofit network member to policy issues). Lead network organizations hold the big picture and build the connection between the mandates of individual network members and the policy network goals (Provan \& Kenis, 2008). This is why many nonprofit policy networks choose to address cross-sector issues related to the labour market, pensions, governance, and the like, rather than topical issues that would be relevant to only a few network members.

Keith Provan and Patrick Kenis (2008) also address the need for network-level competencies. The level of competency required, they argue, depends on the task or goal to be achieved and the external demands and needs 


\section{Elson (2015)}

faced by the network. This speaks to the level of representation on internal networks, whether on ad hoc coalitions or network policy clusters, and the external demands of funding challenges and changes in ministers or government policy priorities. Administrative leads are better suited to address network-level demands, but in order to do so, the administrative lead must have the skills, competencies, and financial capacity to match the needs of the network members (Provan \& Kenis, 2008).

This variable highlights the importance of the size, competence, knowledge, and budgets of policy networks that assume the lead on nonprofit sector policy formulation. The Calgary Chamber of Voluntary Organizations (CCVO), the Ontario Nonprofit Network (ONN) (2014), the Chantier de l'économie sociale (Chantier) (2014), the Réseau québécois de l'action communautaire autonome (RQ-ACA) (2008), and the Community Sector Council of Nova Scotia (CSC-NS) (2015b) are five examples of policy networks where the level of network trust, goal coherence, and administrative competency appears to match the needs of network members (Elson \& Rogers, 2010; interview respondents, 2009, 2011, 2013, \& 2015)."

This is reflected in open and transparent policy formulation processes (e.g., work groups), member accountability and response mechanisms (e.g., forums, surveys), and staffing levels and responsibilities, (e.g., policy and network support staff).

A second dimension, namely that of centralized or (decentralized) clustered structures adds a locus of control variable within the formal or informal reporting dynamic; resulting in the four dimensions profiled in Figure 1. This is an extension of earlier research that focused on the degree of formality within network structures (Elson, 2008, 2011a).

\section{Figure 1: Classification of policy network}

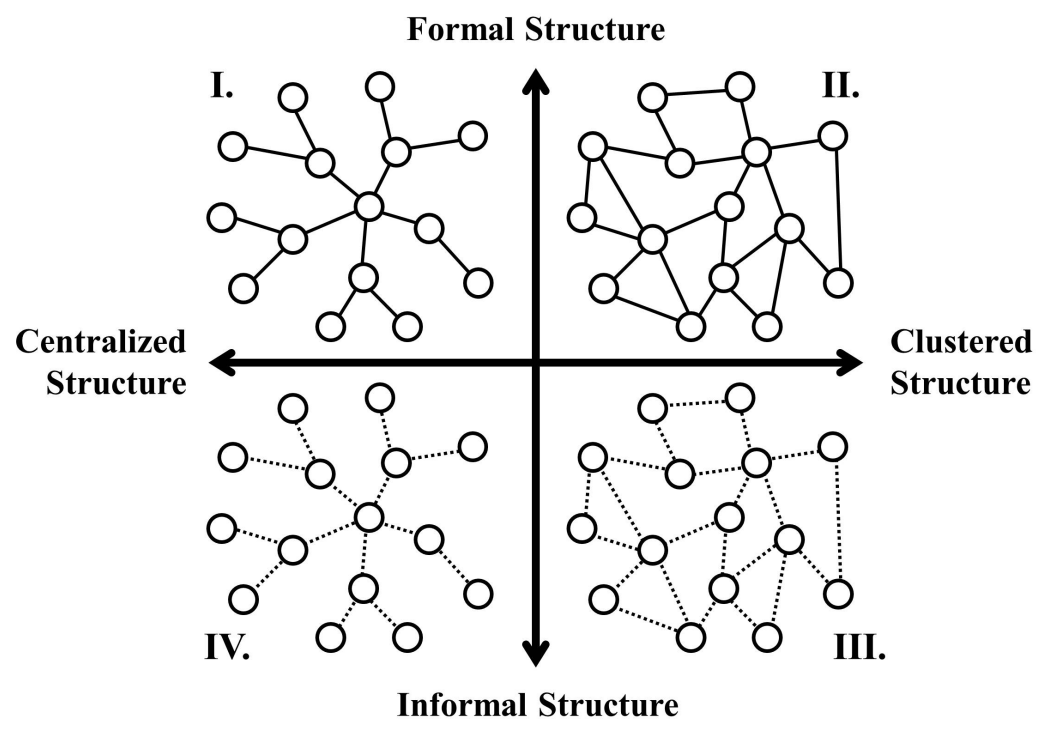

Source: Willems \& Jegers, 2012, p. 72.

Formal, centralized structures (Type I) have a central actor with control over information/knowledge shared and/or the actions of others (e.g., the Chantier). In a formal, clustered, or lateral relationship (Type II), parties operate under formal agreements or rules of conduct, yet the actors have equal power and status in the relationship (e.g., a 
dedicated coalition with a Memorandum of Understanding or MOU). There is reciprocity in this relationship, and the relationship is based on a mutual exchange of information and knowledge. In an informal, clustered structure (Type III), rules, if any, are flexible, implicit, and unwritten. The content of the relationship is based on culture, habits, and beliefs (e.g., internal patterns that emerge within a well-established policy network). In an informal, centralized structure (Type IV), the relationship may be based on an particular ideology or sense of "community" (e.g., Community Sector Council) (Willems \& Jegers, 2012). Willems and Jegers (2012) clearly note that while this framework is divided into quadrants, the reality is much more of a continuum and organizations certainly move from one quadrant to another. The Ontario Nonprofit Network (ONN) is an example of a policy network that has, since its inception, moved from Type IV to Type I.

\section{NONPROFIT POLICY NETWORKS}

Table 1 shows that five provinces (Newfoundland and Labrador, Nova Scotia, New Brunswick, Ontario, and British Columbia) developed a mechanism for sustained policy dialogue following the end of the Voluntary Sector Initiative (2000-2005), while three provinces, Alberta, Saskatchewan, and Manitoba, initiated a nonprofit sector policy while the Voluntary Sector Initiative was still underway (Voluntary Sector Initiative, 2008). Provincial governments did not participate in the Voluntary Sector Initiative, nor were they mandated in any way to do so, but they were certainly kept informed of its developments (Brock, 2010), as were provincial and local nonprofit associations. Between 1995 and 2000, Québec saw the emergence of two substantive policy networks, the Chantier de l'économie sociale and the Réseau québécois de l'action communautaire autonome, which were founded as collective responses to the state of poverty and unemployment in Québec and the 1995 Women's March for "Bread and Roses" (Mendell \& Rouzier, 2006). Prince Edward Island is the only province that has yet to formally engage its nonprofit sector, although there have been attempts by nonprofit sector organizations to articulate common issues (Community Foundation of PEl, 2011). Canada's three territories also lack dedicated nonprofit networks, although there are collective arctic-wide networks related to resource development and sustainability (e.g., the Canadian Circumpolar Institute and Resources and Sustainable Development in the Arctic). This absence could be attributed to the lack of a critical mass of established and well-funded nonprofit sector organizations to assume the lead in developing a network.

Table 1: Collective provincial nonprofit sector policy agenda (years)*

\begin{tabular}{|c|c|c|c|c|c|c|c|c|c|c|c|}
\hline Province/Year & 1995 & 2000 & 2002 & 2004 & 2006 & 2008 & 2010 & 2012 & 2013 & 2014 & 2015 \\
\hline $\begin{array}{l}\text { British } \\
\text { Columbia }\end{array}$ & & & & & & & & & ? & & \\
\hline Alberta & & & & & & & & $\rightarrow$ & ? & - & \\
\hline Saskatchewan & & & & & & & & & & & \\
\hline Manitoba & & & & & & & & & & & \\
\hline Ontario & & & & & & & & & & & \\
\hline Québec & & & & & & & & & & & \\
\hline New Brunswick & & & & & & & & & & & \\
\hline Nova Scotia & & & & & & & & & & & \\
\hline $\begin{array}{l}\text { Newfoundland } \\
\text { and Labrador }\end{array}$ & & & & & & & & & & & \\
\hline
\end{tabular}

${ }^{*}$ The bars mark the years in which a collective nonprofit sector policy agenda has been in place.

In 1995, Québec was the only province exerting a collective government policy agenda for the nonprofit sector ${ }^{1}$ dedicated to addressing the issues of poverty and unemployment (Laforest, 2007). By 2011, six of ten provinces 


\section{Elson (2015)}

(Alberta, Manitoba, Ontario, Québec, Nova Scotia, Newfoundland and Labrador) had an affiliated minister or deputy minister responsible for the relationship of provincial governments with their nonprofit sectors. Three other provinces (British Columbia, Saskatchewan, ${ }^{2}$ and New Brunswick) developed collective bilateral policy networks that engaged the social service segment of the nonprofit sector (Campbell \& Speevak Sladowski, 2009; Carter \& Speevak Sladowski, 2008; Elson, 2011b). Saskatchewan and New Brunswick continue to operate within a policyfocused committee structure, Saskatchewan for human services and New Brunswick for economic and social inclusion (Economic and Social Inclusion Corporation, 2011; Human Services Integration Forum, 2010).

\section{Variances in network representation}

There is considerable variance in how the nonprofit sector is represented in policy forums across provinces. In several provinces, the provincial government officially appoints nonprofit "representatives," and while informally nominated by recognized leaders within the nonprofit sector, their official status is one of an individual rather than collective representation (interview respondent ab2, 2015). In other words, they speak for themselves, not as a representative of the nonprofit sector. Examples of this type representation can be found in the former Government Non-Profit Initiative in BC and the current Alberta Nonprofit and Voluntary Sector Initiative (ANVSI) (Alberta Culture and Tourism, 2015a; The Government/Non-Profit Initiative, 2009).

In other provinces the nonprofit sector is collectively recognized through autonomous nonprofit policy networks. Examples include the Manitoba Federation of Non-Profit Organizations, the Ontario Nonprofit Network, the Chantier de l'économie sociale and the Réseau québécois de l'action communautaire autonome in Québec, and the Community Sector Council of Nova Scotia. These nonprofit policy networks take the lead role of collectively representing the nonprofit sector within their respective jurisdictions. These kinds of policy networks are mutually recognized sector representatives and designate their own representatives to government policy forums and committees accordingly. The Community Sector Council Newfoundland and Labrador is also a nonprofit sector policy network, as is the emergent Saskatchewan Nonprofit Partnership.

\section{Administrative leads in nonprofit networks}

In British Columbia, a number of policy networks represent different constituencies within the nonprofit sector. These include the Voluntary Organizations Consortium of British Columbia (VOCBC), Board Voice, and Volunteer $B C$ (see Table 2). The VOCBC (2015) is a communications and convening network of provincial and coalition organizations and community benefit organizations. Board Voice (2015) is an organization comprising the volunteer boards of community-based social service agencies dedicated to creating a clear and effective voice for volunteer community-based boards. Volunteer BC (2015a) promotes the value of volunteering in collaboration with volunteer centres across the province. Periodic collaborations among these networks are evident in, for example, the Imagine Canada provincial dialogue sessions and the "Next Steps" initiative (Gent, 2012), but these collaborations are neither consistent nor formalized - a reflection of a Type III network configuration (informal and clustered) (interview respondents, 2015).

A similar dynamic exists in Alberta, where policy networks with administrative leads include the Calgary Chamber of Voluntary Organizations, Volunteer Alberta, and the Edmonton Chamber of Voluntary Organizations. It could be argued that the Calgary Chamber of Voluntary Organizations has a more sophisticated policy network administrative capacity, but other lead organizations also play significant roles in the nonprofit policy process in Alberta, as does the Association of Alberta Agricultural Societies and the Alberta Ecotrust Foundation. In addition, there is an ongoing liaison and a significant level of collaboration (e.g., provincial pre-budget deputations; engagement on the Alberta Voluntary and Nonprofit Sector Initiative) among the three lead organizations that is 
more typical of a Type II than a Type III policy network configuration (Alberta Culture and Tourism, 2015; interview respondents, 2015).

Table 2: Nonprofit sector policy administrative leads

\begin{tabular}{|l|l|}
\hline Province & Nonprofit Sector Policy Network Administrative Lead(s) \\
\hline British Columbia & $\begin{array}{l}\text { Various (e.g,, Voluntary Organizations Consortium of British } \\
\text { Columbia/Board Voice/Volunteer BC) }\end{array}$ \\
\hline Alberta & $\begin{array}{l}\text { Various (e.g., Calgary Chamber of Voluntary Organizations/Volunteer } \\
\text { Alberta/Edmonton Chamber of Voluntary Organizations/ Alberta Ecotrust } \\
\text { Foundation) }\end{array}$ \\
\hline Saskatchewan & $\begin{array}{l}\text { Various (e.g., Saskatchewan Nonprofit Partnership/SaskSport } \\
\text { Inc./SaskCulture/Saskatchewan Parks and Recreation Association) }\end{array}$ \\
\hline Manitoba & Manitoba Federation of Non-Profit Organizations \\
\hline Ontario & Ontario Nonprofit Network \\
\hline Québec & $\begin{array}{l}\text { Chantier de l'économie sociale/Réseau québécois de l'action } \\
\text { communautaire autonome }\end{array}$ \\
\hline New Brunswick & None identified (alignment with Community Inclusion Networks) \\
\hline Nova Scotia & Community Sector Council of Nova Scotia \\
\hline Prince Edward Island & None identified \\
\hline Newfoundland and Labrador & Community Sector Council Newfoundland and Labrador \\
\hline
\end{tabular}

A similar dynamic exists in Alberta, where policy networks with administrative leads include the Calgary Chamber of Voluntary Organizations, Volunteer Alberta, and the Edmonton Chamber of Voluntary Organizations. It could be argued that the Calgary Chamber of Voluntary Organizations has a more sophisticated policy network administrative capacity, but other lead organizations also play significant roles in the nonprofit policy process in Alberta, as does the Association of Alberta Agricultural Societies and the Alberta Ecotrust Foundation. In addition, there is an ongoing liaison and a significant level of collaboration (e.g., provincial pre-budget deputations; engagement on the Alberta Voluntary and Nonprofit Sector Initiative) among the three lead organizations that is more typical of a Type II than a Type III policy network configuration (Alberta Culture and Tourism, 2015; interview respondents, 2015).

In Québec, two organizations dominate the nonprofit policy network landscape, namely the Chantier de l'économie sociale and the Réseau québécois de l'action communautaire autonome (RQ-ACA) (see Table 2). Each represents a different constituency, yet both have attained a high level of political and policy sophistication and administrative acuity and engage in formal policy network processes-both within the two networks and between the networks and the provincial government (Elson \& Rogers, 2010). These are examples of Type I policy networks.

The Manitoba Federation of Non-Profit Organizations (MFNPO), the Ontario Nonprofit Network, the Community Sector Council of Nova Scotia, and the Community Sector Council Newfoundland and Labrador have each established themselves as the representative voice for the nonprofit sector within their respective jurisdictions. In Manitoba and Nova Scotia, the provincial government has funded a labour force adjustment strategy and industryfocused human resource councils. The provincial nonprofit policy networks in Manitoba and Nova Scotia are aligned with this strategy. 
Administrative leads in provincial governments

Typically, existing network structures within provincial governments, rather than new ones, are used as a conduit for internal nonprofit policy dialogue, a reflection of institutional layering (Mahoney \& Thelen, 2010). For example, issues about nonprofit sector-government relations are raised at cabinet meetings, standing committee meetings of deputy ministers, ${ }^{3}$ or informally (interview respondents, 2009, 2011, 2013, 2015. There is considerable variation in internal network structures within provincial governments, which has been described in detail elsewhere (Elson, 2014). Typically though, nonprofit secretariat staff operate informally across departments, operate with powers of persuasion, and work to establish themselves as the "go-to" place for advice on nonprofit sector issues. Only Alberta has a bilateral government-nonprofit policy forum (Alberta Culture and Tourism, 2015a).

\section{POLICY NETWORK STRUCTURES}

Where, then, do nonprofit policy network governance structures within provinces fit in this governance framework? Figure 2 provides a preliminary schematic of this internal network governance structure within nine provinces.

\section{Figure 2: Provincial nonprofit policy network structures}

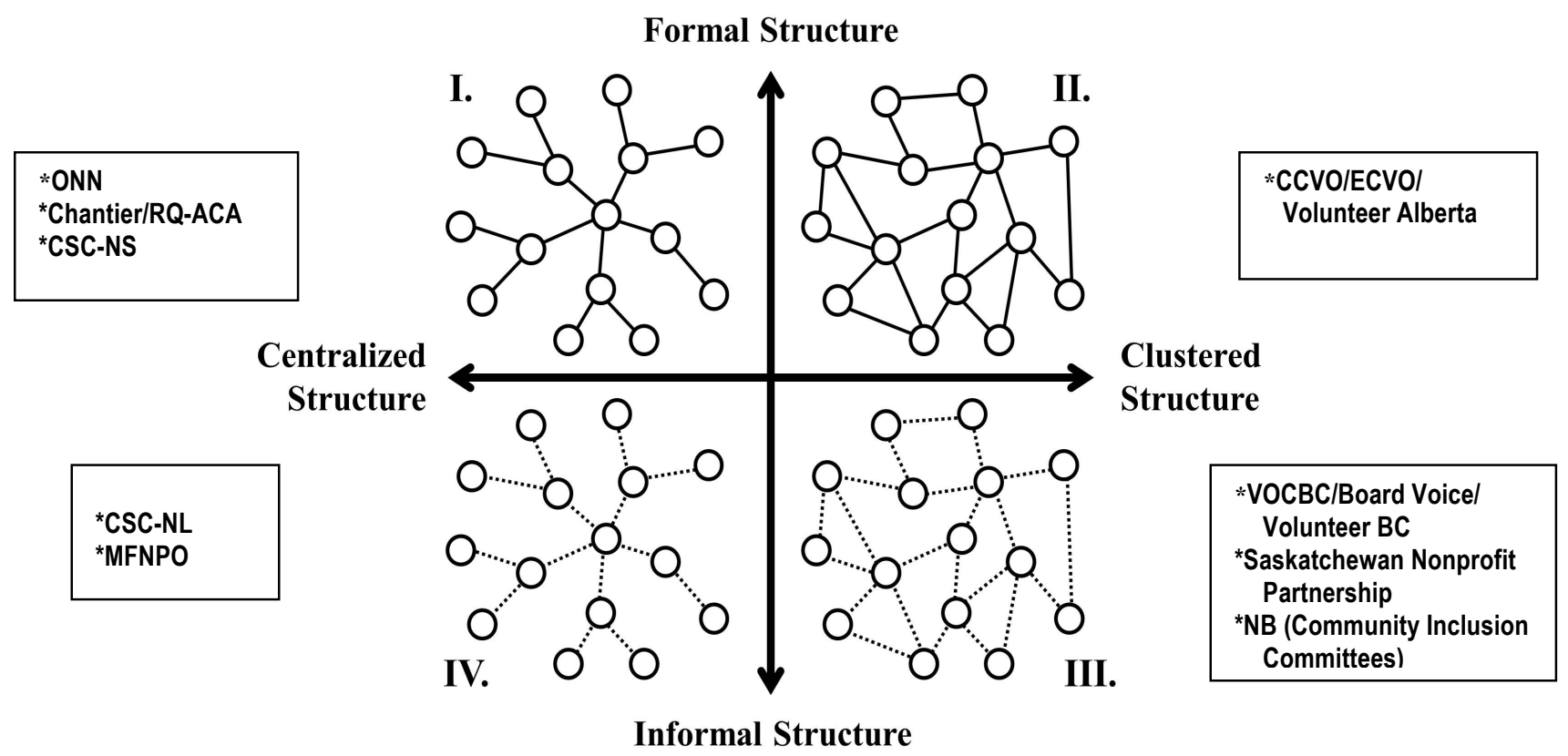

Source: Adapted from Willems \& Jegers, 2012, p. 72

\section{British Columbia}

Until 2013, the primary nonprofit policy forum in British Columbia was the Government Non-Profit Initiative (GNPI), co-hosted by the Ministry of Social Development and Social Innovation (then the Ministry of Housing and Social Development) and the Vancouver Foundation (Wightman \& Siebe, 2011). While focused on social service policy, the GNPI provided an ongoing forum for policy dialogue and periodic joint initiatives, including an annual provincial forum and procurement policy workshops (Ministry of Housing and Social Development, 2009). While the GNPI no 


\title{
Elson (2015)
}

longer exists, what has moved to the policy forefront is Hubcap BC, an initiative of the Partners for Social Impact. Partners for Social Impact is a broad government-private-nonprofit sector forum, organized with support from the Ministry of Social Development and Social Innovation (Hubcap BC, 2015; Ministry of Social Development and Social Innovation, 2015). Both of these BC government-sponsored initiatives leave more nonprofit organizations outside the policy tent than inside.

Nonprofit policy networks in BC are loosely knit and, while they co-exist in a broad nonprofit policy context, there is little glue that binds them together. Board Voice, established in 2009, represents the voice of nonprofit board members in about 70 social service organizations. Board Voice (2015) sees itself as "a clear and effective voice for volunteer community-based boards supporting high quality social services and strong vibrant communities" (n.p.).

The Voluntary Organizations Consortium of British Columbia (VOCBC), initiated in 2002 and unincorporated, is primarily a "network of networks," striving to bring nonprofit organizations of all stripes together. The VOCBC has recently re-branded itself as "proVOCative thinking and has undertaken an initiative called New Directions. New Directions is a collaborative, blended education and training initiative for nonprofit organizations. It combines community conversations and training opportunities; and builds on a similar initiative conducted by Imagine Canada (interview respondent bc, 2015). Imagine Canada (2015), a national organization dedicated to representing and enhancing the role of charities in Canada, has co-sponsored a number of provincial sector dialogue sessions with provincial nonprofit organizations.

Volunteer $\mathrm{BC}$, the voice for strengthening volunteering in $\mathrm{BC}$, is also a strong member of the VOCBC. For example, in collaboration with the Administrators of Volunteer Resources of BC (AVRBC) and the New Directions for BC's Non-Profit Sector Project, Volunteer BC toured the province offering training and community conversation sessions to identify, in part, key features and impacts of the sector in order to create a new sector-based narrative (Volunteer $B C, 2015)$.

Belying this recent collaborative initiative is a history of government and nonprofit umbrella initiatives that have left individual organizations suspicious and burned out. Often competitive contracting through BC Bid leaves organizations wary about sharing information; and there are more examples than sector leaders can count of provincial initiatives that have been announced with great fanfare only to wither on the vine (Lindquist \& Vakil, in forthcoming). As a Type III policy network structure (informal and clustered), nonprofit policy networks in BC readily accept the value of the sector to society in general and communities in particular, but collaboration is inconsistent. To date, no one policy network is seen as a leader for the sector as a whole.

\begin{abstract}
Alberta
In Alberta, the Alberta Nonprofit and Voluntary Sector Initiative (ANVSI) went on hiatus in 2012 for reasons similar to those in BC: a significant change in political leadership and internal government reorganization. The difference in Alberta is that a leaner and more focused ANVSI Leaders Council and Stewardship Forum emerged from the ashes of the former ANVSI (interview respondent ab2, ab1, 2015).

There appears to be a movement toward greater policy alignment ${ }^{4}$ and having the right players around the tablenot just to build better relationships but also to implement public policy (interview respondent ab2, 2015). Membership in the ANVSI has shrunk from eighteen to nine members and the Leaders Council and Stewardship Forum has been introduced. Nonprofit sector membership, via an official Cabinet appointment process, is currently drawn from the Calgary Chamber of Voluntary Organizations, the Edmonton Chamber of Voluntary Organizations,
\end{abstract}




\section{Elson (2015)}

Volunteer Alberta, the Association of Alberta Agricultural Societies, and the Alberta EcoTrust Foundation (Alberta Culture and Tourism, 2015b). The approval process on the government side leaves the final arbiter of nonprofit representation on ANVSI to the provincial government and there are times when nominees have both been rejected and augmented (interview respondent ab2, 2015).

At this time, the provincial government is represented by deputy ministers from Alberta Culture and Tourism, Alberta Human Services, and the Executive Council of Cabinet who attend ANVSI meetings (no substitutions are allowed). The progress to date appears to be encouraging as constellations of activity pertaining to nonprofit data and labour market issues have emerged (interview respondents ab2, ab3 2015). Less fully developed is a new Stewardship Forum, intended to widen the formal engagement of other sector organizations and government departments in this bilateral policy forum.

Alberta Culture and Tourism has been the administrative lead on the nonprofit sector file for a number of years, and continues to act as a catalyst for broad sector-wide discussions within government (interview respondent ab2, 2015). Other ministries, such as Alberta Human Services, have an important funding regime relationship with the sector, and other ministries are called in on an issue-specific basis. In the manner of the now defunct Government and Non-Profit Initiative in BC, this forum is more of a "think tank" and issue resolution forum than a formal deputation and issue resolution process.

There is a substantial degree of consultation and policy strategizing that takes place among the Calgary Chamber of Voluntary Organizations, the Edmonton Chamber of Voluntary Organizations, and Volunteer Alberta, although there are times when other organizations are also involved, or the three organizations act independently, depending on the policy focus. This arrangement is informal, although there are times when an MOU is created. A wide variety of sources is used to both identify and prioritize policy issues, including network members, polling and survey data, and members of the boards of directors; but the administrative leads for these policy networks are executive and policy staff within the policy networks (interview respondent ab1, 2015). Alberta, a Type II network structure (formal and clustered), has achieved consensus on the overall goal of enhancing the contribution of the nonprofit sector in the province, yet exhibits segmentation among policy networks to work on particular aspects of that goal.

\section{Saskatchewan}

The Saskatchewan Nonprofit Partnership (SNP) (recently re-branded from the Saskatchewan Network of Nonprofit Organizations), is a burgeoning unincorporated network in the process of following up from a series of regional consultations and a 2012 provincial summit to assess the appetite for such a policy network (Langen, 2012). Like the VOCBC, the goal of the SNP is to be as inclusive as possible, to operate independent of government, and to operate from a shared or distributed leadership model (interview respondent sk1, 2015).

At this time, the SNP steering committee (nine members) is considering action in the areas of government relations, labour market initiatives, and nonprofit research. Its intention is to provide tangible evidence of the value of a policy network cluster before formalizing any organizational processes. It is pertinent to note there is broad representation on the steering committee. Members include representatives from the United Way (two), nonprofit boards of directors (three), Saskatchewan Parks and Recreation, Saskatchewan Culture, human service organizations (three), and the Community Initiatives Fund (interview respondent sk1, 2015).

Because sport, culture, and parks and recreation groups in Saskatchewan are collectively the exclusive beneficiary of provincial lottery funds, they have a significant capacity to engage in a policy network and engage grassroots 


\section{Elson (2015)}

organizations (Gidluck, forthcoming) should they wish to. The informal and clustered (Type III) structure nature of the Saskatchewan Nonprofit Partnership has been deliberately chosen to build the network from the ground up. Over time it hopes to increase both its capacity and reach across the province.

\section{Manitoba}

In Manitoba, the administrative lead with respect to the nonprofit policy network is the Manitoba Federation of Nonprofit Organizations (MFNPO). The lead department for the nonprofit sector in the provincial government is the Department of Housing and Community Development, while the Department of Entrepreneurship, Training and Trade assumes the lead on labour market adjustment and corresponding sector councils. The MFNPO is a member of the Alliance of Manitoba Sector Councils, and this membership has influenced its policy network priorities, including, for example, the promotion of the Canada Job Grant program to the nonprofit sector (interview respondent mb1).

The MFNPO works hard to hold its attention on other (non-labour) issues, such as legislative agendas, sales tax increases, and contracting regime developments (Frankel \& Levasseur, forthcoming; interview respondent mb1, 2015). Like the CCVO in Alberta, the MFNPO uses a number of sources to determine its policy priorities, particularly its board of directors. Since the MFNPO does not have a membership base, it is a centralized representative of the nonprofit sector in the province and operates as a Type IV (centralized, informal) "network of networks" (interview respondent mb2, 2015).

\section{Ontario}

The Ontario Nonprofit Network (ONN) is a dedicated public benefit action-oriented policy network. Recently incorporated after seven years spent building its constituent base and policy network capacity under the umbrella of the Centre for Social Innovation, the ONN (2015) has 7,000 social media followers, more than 300 volunteer leaders providing time and expertise, eight full-time staff, and six volunteer board members. Although the ONN has individual nonprofit organizations as members, individuals as supporters, and others as social media subscribers, it sees itself as neither an organization nor an association. There are no standing committees in the ONN, but rather ad hoc workgroups that ebb and flow according to policy priorities and network members' interests (interview respondent on1, 2015). Yet, like any organized network, it has a board of directors, a policy committee, an outstanding annual conference, and processes in place to manage policy investments and workgroup formations (Ontario Nonprofit Network, 2014). This gives the ONN a unique Type II (formal and clustered) network structure.

Policy priorities are determined by their congruence and readiness for concrete action in relation to the ONN's mission, vision, and values. The ONN's mandate is to engage, advocate, and lead with-and for-nonprofit and charitable organizations that work for the public benefit in Ontario, and to work toward policy and systemic change (Ontario Nonprofit Network, 2015). At a practical level, policy priorities are also determined by the availability of energy and resources, active sector engagement, and strategic opportunities to make a difference. Active sector engagement brings the ONN's convening capacity to the fore, both within the ONN, regional networks, and other policy-related groups.

The ONN does have a policy committee, and as with other facets of the ONN's network approach, there is constant communication and a collective responsibility among committee members and policy staff. This arrangement enables both the focus required to get policy issues addressed and the flexibility to respond to new developments (interview respondent on1, 2015). Current working groups are the Rural Social Enterprise, Connect the Sector, 


\section{Elson (2015)}

Shared Platforms, and the Ontario Social Economy Roundtable. The ONN (2015) has substantial reach across the provincial government.

The ONN's policy network capacity has been developed with the explicit intention of engaging as many people as possible across as many sub-sectors as possible in broad cross-sector issues (interview respondent on1, 2015). A prime example of this policy engagement is the role the ONN (2014) has played in the evolution of the Ontario Notfor-Profit Corporations Act and in creating nonprofit access to surplus Ontario government land. The ONN regularly connects with more than ten provincial ministries to engage in a policy dialogue and as a member of joint working groups with ministries such as citizenship, finance, treasure board, economic development, employment and infrastructure, and the attorney general (interview respondent on1, 2015).

\section{Québec}

For almost two decades in Québec, the social economy and social justice movements have built and consolidated their representation in the Chantier de l'économie sociale and the Réseau québécois de l'action communautaire autonome (RQ-ACA). The main policy forum for the RQ-ACA representation in the provincial government is the Secrétariat à l'action communautaire autonome within the government Ministry of Employment and Social Solidarity (Ministère du Travail, de l'Emploi et de la Solidarité sociale, 2001). The Chantier's structural point of entry, although by no means the only one, is the Ministère des Affaires municipales et Occupation du territoire. The RQ-ACA, like the Chantier de l'économie sociale, has its origins in the "Bread and Roses" Women's March in 1995 and the subsequent socioeconomic summit in 1996 (Mendell, 2003). Le Réseau québécois de l'action communautaire autonome (RQ-ACA) was established in 1996 and like the Chantier de l'économie sociale it too operates within a Type I (formal and centralized) network structure.

\section{Chantier de l'économie sociale}

The main objective of the Chantier de l'économie sociale is to promote the social economy as part of the socioeconomic development of Québec and thereby recognize the pluralistic nature of the economy (Chantier de l'économie sociale, 2014). The Chantier de l'économie sociale promotes and supports the emergence, development, and consolidation of businesses and social economy organizations in all sectors of the economy (Chantier de l'économie sociale, 2015). One example is its "valeurs ajoutée" (values added) campaign (Chantier de l'économie sociale, 2012). The Chantier de l'économie sociale is an explicit centralized Type I (formal and centralized) "network of networks," with a formal policy identification, formulation, and approval process.

The Chantier board of directors is composed of 35 members, 27 of which are elected at the Chantier's annual general meeting or general assembly. The board of directors is a strategic planning body and plays a guiding role to link the board and the electoral colleges (the Chantier's designation for its "network of networks"). Consultations prior to the Chantier board of directors' adoption of a policy position generally occur through electoral colleges, which in turn engage their member organizations. Each electoral college is responsible for both hosting meetings of its members throughout the year and for providing the Chantier with a scan of emerging and pressing issues (Elson \& Rogers, 2010; interview respondent qc1, 2009 ). The board of directors, in the case of a budget deputation for example, would formulate its policy priorities from this information. The executive committee then calculates how best to position and present these strategic priorities.

The wide scope of representation of the Chantier across the social economy in Québec-combined with its capacity to capture, formulate, and represent the policy interests of its members and its internal organizational capacity- 


\section{Elson (2015)}

gives it a powerful platform from which to engage with the provincial government and to act as a representative of the social economy in Québec internationally.

Le Réseau québécois de l'action communautaire autonome

The Réseau québécois de l'action communautaire autonome (RQ-ACA) is the designated intermediary for organizations and groups in Québec that engage in autonomous community action, namely the leading networks and associations representing the 4,000 autonomous community action agencies across the province that lead the struggle for greater social inclusion, equality, social justice, antiglobalization, and diversity (Elson \& Rogers, 2010; Réseau québécoise de l'action communautaire autonome, 2013).

The RQ-ACA has one primary source of funding: a core operating grant from the provincial Secretariat for Autonomous Community Action. This funding supports three full-time staff members and a provincial office in Montreal. It also provides the capacity for advocacy work across multiple ministries without fear of financial retribution (interview respondent qc2, 2009). The RQ-ACA closely monitors funding for autonomous community action across 22 provincial ministries.

Policy positions must be explicitly consistent with the values of the organization and are approved by members at the annual general meeting, either individually or as part of the approval of the annual action plan. Subsequently, when policy positions are taken, they are ratified by the board of directors and presented to policy makers by the RQ-ACA president or the designated representative (interview respondent qc2, 2009).

The strength of the RQ-ACA lies in its commitment to social justice and democratic action both in the affairs of the association and Québec society at large. While the RQ-ACA may be seen as a thorn in the side of some government officials and more economy-centred organizations, it consistently speaks for, and represents, the community voice of a wide spectrum of grassroots organizations collectively committed to achieving social justice and greater equality, inclusion, and diversity in the province of Québec.

\section{New Brunswick}

There is no designated nonprofit policy network in New Brunswick. The network that does exist operates under the auspices of the Economic and Social Inclusion Corporation. The Economic and Social Inclusion Corporation (2011) is a crown agency mandated under the Economic and Social Inclusion Act to reduce income poverty by 25 percent and deep income poverty by 50 percent by 2015. The Economic and Social Inclusion Corporation is charged with making significant progress in achieving sustained economic and social inclusion.

With the creation of the Department of Healthy and Inclusive Communities in 2012, New Brunswick aligned both its internal departmental structure and its nonprofit sector administrative lead with the Economic and Social Inclusion Corporation (interview respondent nb1, 2013). The minister for Healthy and Inclusive Communities is also the cochair of the board of the Economic and Social Inclusion Corporation. The approval of a social enterprise policy framework for the province (Advisory Committee on Social Enterprise and Community Investment Funds \& Corporation, 2012) is a recent manifestation of this mandate. Twelve regional Community Inclusion Networks throughout the province provide a policy venue for nonprofit engagement, together with a broad range of other community, nonprofit, and business representatives. 


\section{Elson (2015)}

\section{Nova Scotia}

The launch of the Community Sector Council of Nova Scotia in December 2012 was the culmination of more than two years hard work by key nonprofit sector organizations to align the council and its policies and put it on a better footing with the provincial government (Community Sector Council of Nova Scotia, 2014; Phoenix Youth Services \& FOCO, 2012). Like the Manitoba Federation of Non-Profit Organizations, the Community Sector Council in Nova Scotia focuses on labour force issues and is a member of the provincial Association of Industry Sector Councils, the purpose of which is to address skills development and human resources (HR) issues (Department of Labour and Advanced Education, 2014). The Ministry of Labour and Advanced Education, under which labour force issues reside, is also the government's administrative lead for provincial government relations with the nonprofit sector.

As a new and developing policy network, the Community Sector Council is focused internally on governance and operational systems and structures and externally on education (e.g., HR management), promoting a collective sector, identifying collective networks, and creating effective partnerships. The Community Sector Council blends network development and training, leaving the question of memberships to a later date (interview respondent ns1, 2015), as did the Ontario Nonprofit Network. In addition to social media, online resources, and regional forums, the Community Sector Council hosts an annual conference (Community Sector Council of Nova Scotia, 2015).

\section{Regional conveners}

The Community Sector Council, hosted by a well-established nonprofit organization, has contacted individuals to act as regional conveners in six regions throughout the province. In addition to board members, the conveners act as a key conduit from the regions to the central office. It appears that this unique arrangement has been mutually beneficial, giving the host organization insights into developments across their own and other regions (interview respondent ns1, 2015). This formal, centralized structure (Type I) formalizes nonprofit sector and regional convener connections within the provincial network.

\section{Policy engagement}

As a new voice for the nonprofit sector there is no lack of policy issues of interest to the Community Sector Council. Multiyear funding, employee benefits and pensions, contract reporting mechanisms, and impact measurement are some of the policy issues that have come to the fore. Care has been taken to brief members of the Legislative Assembly (MLAs) on Community Sector Council activities and there is consistent and regular contact with ministers and deputy ministers (interview respondent ns1, 2015).

\section{Newfoundland and Labrador}

The Community Sector Council, established in 1976, has played a leading role as both a nonprofit network and policy advocate in Newfoundland and Labrador. The Community Sector Council most often advocates for the nonprofit sector's contribution to poverty reduction, volunteerism, and community sustainability (Community Sector Council Newfoundland and Labrador, 2014). While the Community Sector Council provides training, facilitation, and network building for and with sector and community leaders in a wide variety of areas, it also acts as a conduit for student placements and online access to news, resources, and programs.

Networks fostered by the Community Sector Council do not have a reporting or representative relationship. An example of this informal consultative relationship (Type IV, informal and centralized) is the establishment of a "pulse panel" of community leaders who agree to be surveyed online regarding policy issues on a quarterly basis. This development of a more systematic survey approach followed the completion of a number of periodic surveys of trends and issues (Community Sector Council Newfoundland and Labrador, 2014). 
For its part, the government of Newfoundland and Labrador appointed the first provincial minister in Canada to be responsible for the nonprofit sector in 2007. A Voluntary and Non-Profit Secretariat (VNPS) now operates as a subset of the Office of Public Engagement (2015). While the policy currency and staffing levels of the secretariat have varied considerably over time, three provincial summits have been held (in 2010, 2012, and 2014)-initially to formulate a "roadmap" for action, and later to take the pulse of the sector, including the role of social enterprise ( interview respondent nl1, 2014; Voluntary and Non-Profit Secretariat, 2013).

\section{PROVINCIAL GOVERNMENT POLICY NETWORKS}

More formal network governance structures appear to exist in Manitoba, Ontario, New Brunswick, and Québec (see Table 3). Each has a centralized governance structure at multiple levels up to and including cabinet ministers. There is a vetting process to ensure that policies are implemented and programs are consistent with these policies, going as far, as is the case in New Brunswick and Québec, as to have multiple sectors actively engaged in the policy process (Elson, 2014).

Table 3: Comparative network structures (nonprofit/government [GOV])

\begin{tabular}{|c|c|c|c|c|c|c|c|c|}
\hline Province & \multicolumn{2}{|c|}{$\begin{array}{l}\text { Type I } \\
\text { (formal, centralized) }\end{array}$} & \multicolumn{2}{|c|}{$\begin{array}{l}\text { Type II } \\
\text { (formal, clustered) }\end{array}$} & \multicolumn{2}{|c|}{$\begin{array}{l}\text { Type III } \\
\text { (informal, clustered) }\end{array}$} & \multicolumn{2}{|c|}{$\begin{array}{l}\text { Type IV (informal, } \\
\text { centralized) }\end{array}$} \\
\hline $\mathrm{BC}$ & & & & & & $\begin{array}{l}\text { VOCBCl } \\
\text { Board Voice/ } \\
\text { Volunteer BC }\end{array}$ & GOV & \\
\hline $\mathrm{AB}$ & & & GOV & $\begin{array}{l}\text { CCVO/ } \\
\text { ECVO/ } \\
\text { Volunteer } \\
\text { Alberta }\end{array}$ & & & & \\
\hline SK & & & & & GOV & $\begin{array}{l}\text { SNP/ } \\
\text { SaskSport/ } \\
\text { SaskCulture/ } \\
\text { SPRA }\end{array}$ & & \\
\hline MB & GOV & & & & & & & MFNPO \\
\hline $\mathrm{ON}$ & GOV & ONN & & & & & & \\
\hline$Q \mathrm{QC}$ & GOV & $\begin{array}{l}\text { Chantier/ } \\
\text { RQ-ACA }\end{array}$ & & & & & & \\
\hline NB & & & & & GOV & $\begin{array}{l}\text { Community } \\
\text { Inclusion } \\
\text { Committees }\end{array}$ & & \\
\hline NS & & CSC-NS & & & & & GOV & \\
\hline $\mathrm{NL}$ & & & & & & & GOV & CSC-NL \\
\hline
\end{tabular}

A less formal, yet centralized policy network governance structure was found in British Columbia, Nova Scotia, and Newfoundland and Labrador (see Table 3). In these cases there is a centralized policy focus and a responsible ministry. In Nova Scotia, for example, there is a small and dedicated voluntary sector component within the Ministry 


\section{Elson (2015)}

of Labour and Advanced Education; and there are also significant initiatives underway through the Department of Economic and Rural Development and Tourism (Elson, 2014). This governance structure is reflected in Table 3.

In Alberta and Saskatchewan, the governance structure is less formal and occurs in multiple ministries. In Alberta, Alberta Culture plays an active role, as does Human Services, in some way dividing the sector into expressive and instrumental organizations respectively. However, one would be hard pressed to find a singular focus for nonprofit sector policy either within the government as a whole, or in one particular ministry. In Saskatchewan the expressive side of the nonprofit sector policy file (sport, culture, and recreation) is addressed by the Ministry of Parks, Culture and Sport and the instrumental (service delivery) side is addressed through the Ministries of Education and Social Services (Elson, 2014).

Where network governance is more formal and centralized (Type I), a different picture emerges. The first observation concerns where in the bureaucracy this centralization occurs. In Manitoba, Ontario, and Québec this centralization occurs within a crosscutting ministry (Housing and Community Development in Manitoba; the cabinet in Ontario; and a partnership of two central ministries-the Ministère des Affaires municipales et de l'Occupation du territoire and the Ministère et de l'Économie-in Québec). The Ministry of Housing and Community Development in Manitoba has consolidated its centralized position by leading a crosscutting nonprofit sector funding reform initiative, and is the designated lead on nonprofit sector policy (Frankel \& Levasseur, forthcoming; interview respondent mb1, 2013). In Ontario, the cabinet serves as a vetting and allocation point on nonprofit sector strategies while in Québec, the newly minted Social Economy Law centralizes the coordination and implementation of nonprofit sector (read: social economy) policy (Gouvernement du Québec, 2013; interview respondent, 2013).

\section{DISCUSSION}

The evolution of nonprofit sector-government relations at the provincial level in Canada is undergoing a remarkable wave of change. Some of this change has been driven by the mutual recognition of a substantial and hidden relationship brought to light, in part, by the 2005 National Survey of Voluntary and Nonprofit Organizations. ${ }^{5}$ In other cases, provincial issues of poverty, unemployment, fiscal austerity, and an uncoordinated and under resourced service delivery system have brought the two sectors to the policy table.

The burgeoning sectoral policy relationship that developed relatively simultaneously across multiple provinces was based on a number of common issues. Some of these issues, particularly those related to funding, human resources, capacity building, and volunteer management, were profiled in reports related to the Voluntary Sector Initiative (Human Resources and Social Development Canada, 2009; Social Development Canada, 2004). The fact that these issues existed was not new to either the nonprofit sector or provincial governments. The national survey helped to elevate nonprofit policies from anecdotal stories to system governance issues; particularly when placed in the context of the dominant role Canadian nonprofit sector organizations play in the co-production of human services (Vaillancourt, 2009).

Complementing this development, an informal (Type IV, informal and centralized) policy network, the Canadian Federation of Voluntary Sector Networks (2012) was established in 2002. Monthly teleconferences have been held among network members approximately every 18 months since 2008, and a national "gathering of counterparts" (nonprofit and provincial government representatives) was also held (Canadian Federation of Voluntary Sector Networks, 2008). 


\section{Elson (2015)}

Another characteristic of the third wave of policy dialogue has been the emergence of formal bilateral policy networks designed to address crosscutting issues. This was the case in British Columbia's GNPI and is currently the case for the ANVSI in Alberta. An informal version of a government-sponsored bilateral policy network (nonexclusive) exists in Saskatchewan through Regional Intersectoral Committees and in New Brunswick with the Community Inclusion Committees established by the Economic and Social Inclusion Agency (2011) (Human Services Integration Forum, 2010). Other provinces have seen the emergence of a more centralized policy network structure, independent of government, where a policy network creates either formal-Ontario, ONN; Québec, Chantier/ RQ-ACA; Nova Scotia, Community Sector Council of Nova Scotia-or informal-Manitoba, MFNPO; Newfoundland and Labrador, Community Sector Council of Newfoundland and Labrador-centralized structures.

The ONN could be easily classified as a Type IV structure (informal, centralized), and it is adamant about maintaining its flexible cluster structure. However, as the ONN has matured as an organization and fostered regional networks, more routinized processes to vet policy positions and network developments have been put in place, signalling the transition to a Type I (centralized, formal) structure. This Type I structure will likely provide a balance between the ONN's desired level of flexibility and accountability as an expanding policy network.

In other provinces there is a clustered or decentralized policy network structure due to the existence of multiple nonprofit policy networks. In the case of British Columbia, the VOCBC, Board Voice, and Volunteer BC maintain an informal liaison that is due more to informal interactions between key actors than a formal strategy. In Alberta, the level of liaison and systematic policy coordination among the CCVO, the ECVO, and Volunteer Alberta is frequent and consistent enough to reflect a more structured and formalized relationship than one sees in British Columbia. The Saskatchewan Nonprofit Partnership (SNP) is emergent, much like the ONN was in Ontario in 2006-2007. While at this point, the SNP is dedicated to an inclusive and flexible network model, the long-standing and dedicated policy networks represented by SaskSport, Sask Culture, and the Saskatchewan Parks and Recreation Association cannot be ignored (Gidluck, forthcoming). Over time, the SNP could become more centralized (Type IV), or establish more formal connections with sister policy networks (Type II).

The existence of individual or collective nonprofit sector representation, while necessary for a sustainable policy dialogue to be established, is not sufficient. Political will on the part of governments is also required, and this willingness appears to be tied to the alignment of the nonprofit sector to poverty reduction, community economic development, service delivery, and to a lesser extent, volunteerism (Elson, 2011). The neoliberal contract culture that took hold in Canada in the mid-1990s, displacing citizenship-based project funding during a time of massive deficits at the federal and provincial level, has not been significantly modified with either the establishment of intersectoral partnership agreements or variances in economic conditions (Elson, 2011b).

\section{Comparative analysis}

Table 3 provides some preliminary results concerning the comparative policy network structures within provinces. In Ontario and Québec similarly formal and centralized structures exist (Type I). Manitoba and Nova Scotia share centralized policy structure characteristics, while differing in the level of formality within those structures. Alberta's nonprofit policy network structure (formal and clustered) shares characteristics with the formal and clustered structure within the provincial government, particularly with the new configuration of the ANVSI (interview respondent ab1, ab2, 2015). New Brunswick and Saskatchewan share a similar structure (informal, clustered), both inside government and in the nonprofit sector, as does Newfoundland and Labrador (informal, centralized). In British Columbia there is a common informal structure inside government and the nonprofit sector, the difference being that a degree of centralization exists in the provincial government that is absent in the nonprofit sector. 


\section{Elson (2015)}

It is beyond the scope of this article to systematically address all the reasons why each of these nonprofit networks have emerged and the forms they have chosen. While no means exhaustive, here are four common elements associated with network development observed over seven years of interviews (2009, 2011, 2013, and 2015) and ongoing monitoring of nonprofit-provincial government relationships. First, a critical mass of lead organizations, and individuals from those organizations who see themselves as network and sector (as distinct from organization) builders, and are prepared to invest time and resources in building a sector-wide network. Second, there is a catalytic event that galvanizes and mobilizes both the network leaders and the nonprofit sector as a whole. This event provides both the opportunity for a conversation that transcends individual organizations and the rational to invest in a sustainable network. Otherwise, less formal network structures are either still emergent (Saskatchewan), or operate within provincial government program networks (New Brunswick).

Third, there are few nonprofit network structures that have emerged fully formed. Most networks have undergone an emergent experimental phase in which a prototype network structure has failed to sustain itself, existed only as long as government funding was available, or required substantive changes. Fourth, lessons learned from this experimental phase, together with a willingness to "try again" and a better understanding of how similar networks have or have not worked in other parts of the country, has resulted in the development of a second, more sustainable network prototype. These four factors pertain to the development of the network itself. If the network is working to establish itself in a climate where a provincial government is explicitly supportive of the nonprofit sector, then this will certainly make a difference, not necessarily to the existence of the network, but likely to its pace of development and long-term policy impact.

\section{Policy outcomes}

What then of the policy outcomes associated with nonprofit networks outlined above? Examples include networks in Alberta (CCVO), Manitoba (MFNPO), Ontario (ONN), and Nova Scotia (CSC-NS) that have each made progress on a number of labour market strategies. Québec (RQ-ACA/Fédération des Femmes du Québec) has established a multiemployer pension plan for the sector and the ONN is advocating for one. Subsequent to the Calgary flood in 2013, the CCVO has taken the lead on sector-related emergency preparedness. The ONN has attained pre-public nonprofit access to the surplus public land registry and to the provincial vendor of record program; and in Manitoba a multiyear funding, and simplified application and reporting pilot program has been introduced and evaluated. Thus the four provinces with organized, formal, and well-resourced networks, Alberta, Ontario, Québec, and Nova Scotia, have also made important inroads in advocating for and achieving tangible policy outcomes. While less formally structured, the Manitoba Federation of Non-Profit Organizations and the Community Sector Council Newfoundland and Labrador have each made some important policy contributions, thus giving a voice to the sector in their respective province. The policy outcomes associated with the numerous nonprofit networks in British Columbia are difficult to identify and it is still too early to assign any policy outcomes to the Saskatchewan Nonprofit Partnership.

\section{CONCLUSION}

There is considerable value in examining the network governance structures within nonprofit policy networks as well as their corresponding provincial governments. Nonprofit sector-government relations do not neatly fit into aligned ministries such as agriculture or tourism, and thus for any substantive policy outcomes there should be a deliberate "placement" of nonprofit sector policy within the overall governance structure. Where and how this policy portfolio is placed says a great deal about the value and status of this file. The more formal governance structures in the governments of Manitoba, Ontario, New Brunswick, and Québec are tied to clear policy goals and oversight by the highest levels of government, including the cabinet office. 
The policy network structures within the nonprofit sector across Canada are centralized where there is a dominant nonprofit policy network and clustered where there are multiple policy networks with dedicated sectoral interests. The degree of formality in the network structures appears to be a reflection of both the maturation of the policy network (emergent or established) and how a lead nonprofit policy network operates in relation to other nonprofit networks. Regardless of the structure of the nonprofit or provincial government policy network, two conclusions can be drawn. First, no configuration isolates one sector from the other, and second, there is a greater degree of compatibility between the nonprofit and government policy network structures than one might expect. Clearly this is an avenue of exploration that would benefit from further investigation and analysis. It is hoped that this research is a meaningful contribution to this area of investigation and to government and nonprofit partners dedicated to furthering their policy relationship for the benefit of Canadians.

\section{ACKNOWLEDGEMENTS}

The author would like to acknowledge the funding and support received over the six years (2009-2015) for this government-nonprofit relations research from the Institute for Community Prosperity, Mount Royal University. It is rare that longitudinal research of this nature is internally supported and for this I am sincerely grateful. A special word of thanks goes to Research Associate Priscilla Wamucii who did a stellar job of transcribing the research interviews. This research would not have been possible without the collaboration of the interviewees from coast to coast, from both provincial governments and the nonprofit sector. The author would also like to express his appreciation to the anonymous reviewers and the copy editor who made extremely valuable comments and suggestions. Any errors or omissions are my responsibility.

\section{ABBREVIATIONS}

Calgary Chamber of Voluntary Organizations (CCVO)

Chantier de l'économie sociale (Chantier)

Community Sector Council Newfoundland and Labrador (CSC-NL)

Community Sector Council-Nova Scotia (CSC-NS)

Edmonton Chamber of Voluntary Organizations (ECVO)

Manitoba Federation of Non-Profit Organizations (MFNPO)

Ontario Nonprofit Network (ONN)

Réseau québécois de l'action communautaire autonome (RQ-ACA)

Saskatchewan Nonprofit Partnership (SNP)

Saskatchewan Parks and Recreation Association (SPRA)

Voluntary Organizations Consortium of British Columbia (VOCBC)

Saskatchewan Parks and Recreation Association (SPRA)

\section{NOTES}

1. There was a Minister of Community Development, Cooperatives and Volunteers (Hon. Jenny Kwan) in British Columbia between 1999 and 2001, but this position was terminated, as were many sector-focused initiatives, when the provincial Liberals defeated the New Democratic Party in 2001.

2. Saskatchewan also has a significant bilateral relationship with its sport, culture, and recreation community, as these three sub-sectors collectively manage the provincial lottery scheme.

3. Deputy minister standing committees are another example of a network structure. 


\section{Elson (2015)}

4. Policy alignment is defined here as the degree to which the configuration of policy interests within government are horizontally (i.e., centralized to clustered) and structurally (i.e., formal to informal) coordinated. In the context of network governance, policy alignment with an administrative lead would be the network goal, requiring, if it is going to be effective, ongoing monitoring, moderately high goal consensus, and a high level of operational competency in operating as a network.

5. The National Survey of Nonprofit and Voluntary Organizations (NSNVO) was the first-ever, large-scale survey of nonprofit and voluntary organizations in Canada. The survey provided detailed data on the size and scope of the voluntary sector in Canada, including types of organizations, what they do, their budgets, and numbers of paid staff and volunteers. The survey also helped clarify the needs and challenges facing the sector by providing data on organizations' perceptions of their strengths and weaknesses.

\section{WEBSITES}

Administrators of Volunteer Resources of BC, http://www.avrbc.com/

Alberta Ecotrust Foundation, http://www.albertaecotrust.com/

Alberta Nonprofit and Voluntary Sector Initiative, http://culture.alberta.ca/community/albertas-voluntary-

sector/nonprofit-voluntary-sector-initiative/

Alliance of Manitoba Sector Councils, http://www.amsc.mb.ca/

Association of Alberta Agricultural Societies, http://www.albertaagsocieties.ca/

BC Bid, http://www.bcbid.gov.bc.ca/open.dll/welcome?language=En

Calgary Chamber of Voluntary Organizations, http://www.calgarycvo.org/

Canadian Circumpolar Institute (CCI), http://www.cci.ualberta.ca/

Centre for Social Innovation, http://socialinnovation.ca/

Edmonton Chamber of Voluntary Organizations, http://www.ecvo.ca/

Manitoba Federation of Non-Profit Organizations, http://www.mfnpo.org/

Resources and Sustainable Development in the Arctic (ReSDA), http://yukonresearch.yukoncollege.yk.ca/resda/

SaskCulture, http://www.saskculture.ca/

Saskatchewan Parks and Recreation Association (SPRA), http://www.spra.sk.ca/

Volunteer Alberta, http://volunteeralberta.ab.ca/

\section{REFERENCES}

Advisory Committee on Social Enterprise and Community Investment Funds. (2012). Learning and earning: Building a social enterprise policy framework. Fredericton, NB: Economic and Social Inclusion Corporation.

Advisory Committee on Social Enterprise and Community Investment Funds, \& Employment aned Social Inclusion Corporation. (2012). Learning and earning: Building a social enterprise policy framework. Fredericton: Economic and Social Inclusion Corporation.

Alberta Culture and Tourism. (2015a). Alberta nonprofittvoluntary sector initiative. URL: http://www.culture.alberta .ca/community/albertas-voluntary-sector/nonprofit-voluntary-sector-initiative/default.aspx [September 23, 2015].

Alberta Culture and Tourism. (2015b). Alberta nonprofit/voluntary sector initiative. URL: http://culture.alberta.ca/ community/albertas-voluntary-sector/nonprofit-voluntary-sector-initiative/

Board Voice. (2015). About. URL: http://boardvoice.ca/public/about/ [May 11, 2015].

Brock, K. L. (2010). A comprehensive Canadian approach to the third sector: Creative tensions and unexpected outcomes. In B. Gidron \& M. Bar (Eds.), Policy initiatives towards the third sector in international perspective. New York: Springer. 


\section{Elson (2015)}

Campbell, M., \& Speevak Sladowski, P. (2009). Building sustainable relationships between nonprofittvoluntary sector and provincial \& territorial governments: An updated Pan Canadian snapshot and summary report of the second gathering of counterparts, February 9-10, Halifax, Nova Scotia. (P. Speevak Sladowski, Ed.). Ottawa: Centre for Voluntary Secor Research and Development.

Canadian Federation of Voluntary Sector Networks. (2008). A gathering of counterparts: Highlight report. Ottawa.

Carter, S., \& Speevak Sladowski, P. (2008). Deliberate relationships between governments and the non-profit sector/voluntary sector: An unfolding picture. Toronto: The Wellesley Institute.

Community Foundation of PEI. (2011). Bulilding the capacity of PEl's third sector: Summary analysis and recommendations. Charlottetown: Community Foundation of PEI.

Community Sector Council Newfoundland and Labrador. (2014). Annual report 2014. St Johns. URL: http:/l communitysector.nl.ca/2014annualreport [November 16, 2015].

Community Sector Council of Nova Scotia. (2014). Abour our sector council. URL: http://csc-ns.ca/ [September 23, 2015].

Community Sector Council of Nova Scotia. (2015). Creating a different kind of profit: Annual report 2014.URL: http://csc-ns.ca/wp-content/uploads/2013/01/CSCNS-2014-Annual-Report-Printable-March-15.pdf [September 23, 2015].

Department of labour and Advanced Education. (2014). What is the sector council program? URL: http:/l workplaceinitiatives.novascotia.ca/sector-council-program/ [September 15, 2015].

Economic and Social Inclusion Corporation. (2011). Overcoming poverty together: The New Brunswick economic and social inclusion plan. URL: http://www2.gnb.ca/content/dam/gnb/Departments/esic/pdf/Plan-e.pdf [September 15, 2015].

Elson, P. R. (2008). A historical institutional analysis of voluntary sector/government relations in Canada. Ontario Institute for Studies in Education. University of Toronto, Toronto.

Elson, P.R. (2010). A slice of the pie: An overview of provincial voluntary sector-government relations in Canada. 7th NVCONSSN "Researching the Voluntary Sector" Conference. Leeds, England.

Elson, P.R. (2011a). High ideals and noble intentions: Voluntary sector-government relations in Canada. Toronto: University of Toronto Press.

Elson, P.R. (2011b). The emergence of structured sub-national voluntary sector-government relations in Canada: A historical institutional analysis. Voluntary Sector Review, 2(2), 135-155.

Elson, P.R. (2012). Canada's voluntary sector initiative and sub-national voluntary sector-government relations: A third wave. Nonprofit Policy Forum, 3(2), Article 4.

Elson, P.R. (2014). Third wave, third sector: A comparative provincial analysis of the governance of third sector relations. Canadian Public Administration, 57(4), 527-547.

Elson, P.R., \& Rogers, D. (2010). Voices of community: The representation of nonprofit organizations and social enterprises in Ontario and Quebec. Toronto: Social Economy Centre, University of Toronto.

Frankel, S., \& Levasseur, K. (forthcoming). A patchwork of funding relationships in Manitoba: From principal-agent towards co-governance. In P. R. Elson (Ed.), Funding policies and the nonprofit sector in Western Canada: Evolving relationships in a changing environment. Manuscript submitted for publication.

Gent, D. (2012). Nonprofit and charitable sector engagement strategy: A regional update from BC following up from the National Summit. Vancouver, BC.

Gidluck, L. (forthcoming). Funding policy and the provincial lottery: Sport, culture and recreation in Saskatchewan. In P. R. Elson (Ed.), Funding policies and the nonprofit sector in Western Canada: Evolving relationships in a changing environment.

Hall, M.H., Barr, C. W., Easwaramoorthy, M., Sokolowski, S. W., \& Salamon, L. M. (2005). The Canadian nonprofit and voluntary sector in comparative perspectives. Toronto: Imagine Canada. 


\section{Elson (2015)}

Hall, M H., de Wit, M.L., Lasby, D., Mclver, D., Evers, T., Johnston, C., ... Murray, V. (2005). Cornerstones of community: Highlights of the national survey of nonprofit and voluntary organizations (2003 revised). Ottawa: Statistics Canada.

Hubcap BC. (2015). BC partners for social impact. URL: http://www.hubcapbc.ca/BC-Partners-for-SocialImpact/BC-Partners-for-Social-Impact.aspx [May 13, 2015].

Human Resources and Social Development Canada. (2009). Voluntary sector initiative impact evaluation: Lessons learned from the voluntary sector initiative (2000 - 2005): Final report. Ottawa: Human Resources and Social Development Canada.

Human Services Integration Forum. (2010). Human services integration forum: 2010-2013 strategic PJplan. Regina: Ministry of Education, Government of Saskatchewan.

Laforest, R. (2007). The politics of state-civil society relations in Quebec. In M. Murphy (Ed.), Canada: The state of the federation 2005 - Quebec and Canada in the new century: New dynamics, new opportunities. Montreal \& Kingston: McGill Queen's University Press.

Langen, S. (2012). Saskatchewan network of nonprofit organizations: Feasibility study \& organizational options. Regina: McNair Business Development Inc.

le Chantier de l'économie sociale. (2012). Spécial loi-cadres sur l'économie Sociale. Bulletin de Chantier, (Novembre). URL: http://suivi.Ink01.com/v/443/2a01427b2a4bcf3688f14585438e41432c10e71d98e9e653 [May 14, 2015].

le Chantier de l'économie sociale. (2014). Rapport annuel 2013-2014. Montreal. URL: http://www.chantier.qc.ca/ userImgs/documents/CLevesque/sitechantierdocuments/RA-Chantier13-14-final.pdf [May 14, 2015].

le Chantier de l'économie sociale. (2015). About us. URL: http://www.chantier.qc.ca/?module=document\&uid=867 [May 14, 2015].

Le gouvernement du Québec. (2013). Passage of Bill 27, the Social Economy Act - The gouvernement du Québec recognizes the contribution of the social economy. URL: http://www.gouv.qc.ca/portail/quebec/pgs/ commun/actualites/actualite/actualites_131010_economie-sociale/?lang=en [May 14, 2015].

Lindquist, E., \& Vakil, T. (forthcoming). Adapting to British Columbia's new era and moving beyond: Relationshipbuilding, funding, and the nonprofit sector. In P.R. Elson (Ed.), Funding policies and the nonprofit sector in Western Canada: Evolving relationships in a changing environment.

Mahoney, J., \& Thelen, K. (2010). A theory of gradual institutional change. In J. Mahoney \& K. Thelen (Eds.), Explaining institutional change: Ambiguity, agency, and power. New York: Cambridge University Press.

Mendell, M. (2003). The social economy in Quebec. Montreal: Concordia University.

Mendell, M., \& Rouzier, R. (2006). Quelques Initiatives ayant permis l'institutionnalisation de l'économie sociale au Québec: Rôle central de al société civile et rôle essential de l'état. Montreal: Alliance de recherche universités-communautés en économie sociale (ARUC-ÉS).

Ministère de l'Emploi et de la Solidarité sociale. (2001). Déclaration nationale sur l'action bénévole. URL: http:/l bel.uqtr.ca/1265/1/6-19-712-20060208-1.pdf [May 13, 2015].

Ministry of Housing and Social Development. (2009). British Columbia government non profit initiative (GNPI). Victoria: Government of British Columbia. URL: http://www.nonprofitinitiative.gov.bc.ca/index.html [May 13, 2015].

Ministry of Social Development and Social Innovation. (2015). BC kicks off social enterprise month. URL: https://news.gov.bc.ca/stories/bc-kicks-off-social-enterprise-month [May 13, 2015].

Office of Public Engagement. (2015). Office of public engagement. URL: http://www.ope.gov.nl.ca/index.html [May 14, 2015].

Ontario Nonprofit Network. (2014). Annual report 2014. Toronto. URL: http://issuu.com/theonn/docs/ onn.annualreport2014/2\#signin [May 14, 2015].

Ontario Nonprofit Network. (2015). Our Network. URL: http://theonn.ca/our-network/ [May 14, 2015]. 


\section{Elson (2015)}

Phoenix Youth Services, \& FOCO. (2012). At the same table: Developing the nonprofit sector in Nova Scotia - A Nova Scotia nonprofit sector research project. Halifax : Phoenix Youth Services/ FOCO.

Provan, K.G., \& Kenis, P. (2008). Modes of network governance: Structure, management, and effectiveness. Journal of Public Administration Research \& Theory (Vol. 18, pp. 229-252). Oxford University Press / USA.

Réseau québécois de l'action communautaire autonome. (2008). Propsition d'éléments à intégrer au Plan d'action gouvernmental en matère d'action communitaire et d'action bénévole 2008-2013. Québec: Réseau québécois de l'action communautaire autonome.

Réseau québécoise de l'action communautaire autonome. (2013). L'action communautaire autonome. Montreal: Réseau québécoise de l'action communautaire autonome. URL: http://www.rq-aca.org/?page_id=10

Sandström, A., \& Carlsson, L. (2008). The performance of policy networks: The relation between network structure and network performance. Policy Studies Journal, 36(4), 497-524.

Social Development Canada. (2004). The voluntary sector initiative Process evaluation: Final evaluation report. Ottawa: Audit and Evaluation Directorate, Social Development Canada.

The Government/Non-Profit Initiative. (2009). The BC story: Building better outcomes \& stronger communities. Vancouver, BC. URL: https://www.vancouverfoundation.ca/sites/default/files/u13/BC-RegionalForum.pdf [May 16, 2015].

Vaillancourt, Y. (2009). Social economy in the co-construction of public policy. Annals of Public and Cooperative Economics, 80(2), 275-313.

Voluntary and Non-Profit Secretariat. (2013). Policy advice. URL: http://www.gov.nl.ca/vnps/policyadvice.html [May 13, 2015].

Voluntary Sector Initiative. (2008). History of the VSI. URL: http://www.vsi-isbc.org/eng/about/history.cfm [May 13, 2015].

Volunteer BC. (2015). Regional training and community conversations. URL: http://www.volunteerbc.bc.ca/ [May 13, 2015].

Wightman, F., \& Siebe, M. (2011). GNPI co-chairs update. Victoria: Government non-profit initiative. URL: http://www.nonprofitinitiative.gov.bc.ca/co-chair_updates.html [May 13, 2015].

Willems, J., \& Jegers, M. (2012). Social movement structures in relation to goals and forms of action: An exploratory model. Canadian Journal of Nonprofit and Social Economy Research, 3(2), 67-81.

\section{ABOUT THE AUTHOR / L'AUTEUR}

Peter R. Elson is Senior Research Fellow, Institute for Community Prosperity, Mount Royal University and Adjunct Assistant Professor, School of Public Administration, University of Victoria. Email: pelson@mtroyal.ca / pelson@uvic.ca . 